\title{
Evaluation and Measurement Among Croatian Public Relations Professionals'
}

Original scientific paper _ DOI 10.22522/cmr20160214 _ received on 7 November 2016 UDK 001.891:659.441.3(497.5) _ 005.57:334.722

\section{Ema Starčić}

Faculty of Political Science, Journalism at the University of Zagreb (graduated student). Email: starcic.ema@gmail.com

\section{Hrvoje Jakopović}

Faculty of Political Science, University of Zagreb. Email: hrvoje.jakopovic@fpzg.hr

\section{Abstract}

This paper examines PR evaluation and measurement in the corporate sector in Croatia. PR evaluation is one of the most important questions for the future of the public relations profession. The authors analyse the PR metrics used in the corporate sector in Croatia. With the survey research, they question awareness concerning PR evaluation, frequency of evaluation performance, what is taken as a measure of PR efficiency, methods used and competencies for using certain methods, evaluation approaches for social media. Survey research conducted on a sample of 35 public relations professionals from 35 different organizations in Croatia shows that measuring the effectiveness of the public relations programme in Croatia is still not fully implemented in practice, but there is a high level of awareness about the importance of evaluation in public relations. Results show that PR professionals prefer to use quantitative methods and that they mostly use evaluation as summative research.

Keywords: evaluation, public relations, corporate communications, corporate sector, PR metrics, Croatia

1 This paper is based on research for Ema Starčić's master's thesis entitled "Načini mjerenja učinkovitosti programa odnosa s javnošću u hrvatskom korporativnom sektoru” and made under the mentorship of Hrvoje Jakopović, PhD (Master's thesis was defended in September, 2016). 


\section{Introduction}

The importance of evaluation in public relations has been discussed since the 1920s in the United States (Watson, Noble, 2005, p. 13). Over time, the issue of PR evaluation became relevant for experts around the world. Various authors developed evaluation models for public relations and applied different research methods in those models (McNamara, 2006; Cutlip et al., 2000; Watson, 1999; Lindenmann, 1993). Not only do these models serve for the better understanding of public relations value but they are also meant to be used in PR practice. From the perspective of strategic communication, methodology for measurement is often grounded on management by objectives (MBO) (Drucker, 1954). Every measure should be taken with regard to the objectives of the PR campaign. Success is determined through measurement of results and achievement of objectives. Nevertheless, evaluation is made to be consistent and to be a part of every step on the way. Therefore, it assumes that PR activities should also be measured during programme execution (Jugo, 2012, p. 244).

However, PR practitioners are confronted with these questions - how to measure programme efficiency in public relations when the outcomes of PR campaigns are hard to follow due to the influence of other variables, but also how to determine when PR really finished the job, considering that objectives and also effects can be short-term and long-term. Furthermore, it is challenging to define the real measure of PR - because PR can influence at a cognitive, affective or behavioural level (Gregory, 2009). While evaluation associated with traditional PR seems unstandardized and fluid, there is a parallel battle going on the front of social media evaluation and handling big data. There is an enormous informational space - user generated content (UGC) that can be easily harvested and used for PR and marketing campaigns. Moreover, different programmes allow real-time analysis of these data.

Studies concerning evaluation in public relations show that these are the most frequent obstacles: time for conducting research, orientation on media coverage, not enough money and knowledge to get evaluation results (Watson, Noble, 2005, p. 33). Recent studies such as the "Excellence in strategic communication - creating communication value through listening, messaging and measurement” (European Communication Monitor, 2015) show that, among more than two thousand PR professionals from 41 country, including Croatia, the majority still emphasizes measurement of outputs in media, while they are more focused 
on the effects on internet and social media. Not enough consideration is given to expenses of the entire communication program. The outflow of communication projects is rarely measured, financial and business goals are not incorporated with public relations efficiency and results. Implementation of evaluation models and methods in Croatian public relations practice, especially in the corporate sector, has not yet been examined in previous studies. However, some of the recent studies indicate that Croatian public relations experts are very aware of how important are the maintenance of positive reputation (49\%), strategic communication (47\%) and digital communication through social media (39\%) (HUOJ, Ipsos Puls, 2013). Measurement and evaluation should therefore be examined very carefully, acknowledging that strategic communication is a necessity in contemporary business in Croatia. This article provides an in-depth perspective on PR evaluation and measurement performance in the Croatian corporate sector. It examines how often PR activities are evaluated, using what research methods and tools, and also what are the reasons for not performing evaluations of PR programmes.

\section{Contemporary approaches}

Evaluation is a complex process of measuring activities in public relations. In its essence, it is research based and, therefore, it is often divided on formative and summative research. Formative research represents the starting position for planning communication activities. It is research necessary for setting objectives and also for tracking activities during programme execution. Summative research is conducted at the end of the programme and it is used for the assessment of objectives. The results of summative research are often presented to the client, board of directors and CEOs. It is not possible to answer the question "how did we do" in a PR campaign without setting measurable objectives and without setting mechanisms for measuring (Gregory, 2006, p. 168).

Likely et al. (2006, as cited in Macnamara, 2014, p. 19) point out several methods used in contemporary PR practice: 1. Return on impressions (ROI) - the approach assumes that a certain number of impressions in the media will raise awareness and that it will affect the attitudes and behaviours of one part of targeted audiences; 2 . Return on media impact (ROMI) - compares media coverage data with sales results over a longer period of time to 
recognize cause and effect; 3 . Return on target influence (ROTI) - uses survey research before and after media exposure for measurement of awareness and buying intentions; 4 . Return on earned media (ROEM) - the approach is based on advertising value equivalency (AVE), a comparison of gained media coverage and publicity with advertisements. Some of these approaches were criticized for not showing the real value of public relations, as is often the case with the AVE method.

The contour of standardization in public relations measurement is slowly emerging with the Barcelona Principles 2.0 (2015), which emphasize the necessity to incorporate measurable goals in PR programs, to measure outcomes and not only outputs, to associate organizational performance with PR campaigns, to use the mixed method approach, to disregard AVE as a method for PR measurement, to use social media measurement software, and to achieve a high level of trustworthiness with transparency and replicability. In terms of standardization, Michaelson and Stacks (2011, p. 20) point out that "public relations' function in relation to ROI is to establish brand, product, service, or issue engagement outcomes dealing with credibility, relationship, reputation, and trust target audience perceptions of that brand, product, service, or issue". Therefore, "engagement" is presented and set as a standardized outcome and measure of public relations activities, while many authors see "image" and "reputation" as possible outcomes of PR programmes (Jakopović, 2015; Löwensberg, 2009; Skoko, 2006).

When it comes to methods used for measuring on a global scale, the annual Global Communications Report shows that reach (68\%), impressions (65\%), and content analysis of news releases (64\%) are the most frequent metrics used for PR measurement (USC Annenberg, 2016). Furthermore, the AVE method is still present in 30\% (USC Annenberg, 2016).

\section{Material and methods}

\subsection{Research aims}

This paper examines the state of the PR profession in Croatia regarding evaluation and measurement. The main aim of this research is to discover in what matter Croatian PR practitioners conduct evaluation and with what methods and tools they measure PR 
activities. Moreover, this research is focused on examining PR professionals who work in the corporate sector in Croatia. The authors want to discover whether there is a reason why evaluation is not performed as a part of strategic communication and to assess the competence of PR professionals to conduct evaluation with a certain research method. The result and research insights should be a starting point for further analysis of evaluation practices in Croatia.

\subsection{Research questions}

RQ1 - How often do PR professionals in the Croatian corporate sector perform evaluation and measurement of PR activities?

RQ2 - What are the reasons for not conducting evaluation and measurement of PR activities?

RQ3 - Which measurement methods are present in Croatian corporations?

RQ4 - In what matter are Croatian PR professionals qualified for doing research and familiar with research methods?

RQ5 - What is the attitude of Croatian PR professionals towards evaluation and measurement in public relations?

RQ6 - What tools and method do Croatian PR professionals use for measurement of PR activities on social media?

\subsection{Sample}

This research is focused on public relations in the profit-oriented corporate sector.

"Corporations are owned by their stockholders (shareholders), who share in profits and losses generated through the firm's operations." (businessdictionary.com, 2016) Corporate communications represent an instrument for management to successfully handle internal and external communication challenges. Therefore, corporate communications effectively coordinate organizational relations with different interest groups, stakeholders (Tench, Yeomans, 2009, p. 269). 
The authors consider public relations as being significantly developed in the corporate sector in terms of corporations and their profit orientation, which leads to necessity for constant growth and improvement to gain customer satisfaction. Therefore, it can be assumed that PR evaluation and measurement in the corporate sector should be on the highest level.

Nonprobability sampling was designed to include a sample from the population of Croatian PR professionals and PR experts with high-ranking positions in public relations in the corporate sector. The population is based on the number of companies that are active in Croatia. Recent data show that there is close to 105000 active companies - small (1049), medium (50-249) and large (over 250) in Croatia (Croatian Chamber of Economy, 2014; Financial Agency, 2015 as cited in CEPOR, 2016). The assumption is that every medium-sized company (1.221 subjects) and large company (354 subjects) in Croatia has a person or department dealing with public relations, therefore, the authors especially take into account the population of 1575 subjects that have a significant need for public relations evaluation. The authors chose the approach of voluntary sampling because of the assumption that research hypotheses are more likely to be confirmed when respondents in orientation research are volunteers (Rosenthal, Rosnow, 1975, as cited in Milas, 2005, p. 407). In this survey research, 35 respondents from the corporate sector in Croatia were included as they match the criteria and correspond to the aforementioned profiles. The authors wanted to gather opinions from different organizational cultures. This approach implies that results will show perspectives on PR evaluation from various organizations in the corporate sector in Croatia. Respondents from domestic and foreign organizations are commensurably represented. The research conducted on the volunteer sample of Croatian PR professionals should, therefore, provide satisfactory insights and produce propositions for future research in this field.

\subsection{Methods and procedures}

The online survey method is applied for analysing trends in PR evaluation and measurement in Croatia and for gaining insights into how Croatian PR professionals use PR metrics. An in-depth questionnaire with 22 questions included Likert scales, numeric scales, openended questions and multiple choices questions. 
The survey was designed and conducted on the online platform LimeSurvey in the Croatian language and with the supporting platform of the University Computing Centre, University of Zagreb (SRCE) (http://limesurvey.srce.hr/, 2016). The survey was available on the link (http://limesurvey.srce.hr/79557/lang-hr) and it was shared with the support of Croatian PR agencies, the Croatian Public Relations Association (HUOJ) and directly sent to PR departments in corporate sector.

\section{Results}

In this survey conducted on 35 public relations experts from the corporate sector, demographic data (Figure 1) shows that most of the respondents are 26-35 (40\%), 36-45 (31\%) and 1825 (23\%) years old. The least represented age group were respondents from 46 to 55 (6\%) years old. As for the gender gap, the survey was completed by a larger number of women than men, 22 women (63\%) and 13 men (37\%). Research about the state of public relations in Croatia (HUOJ, Ipsos Puls, 2013; HUOJ, GfK, 2009) shows also that women are more represented (72\%).

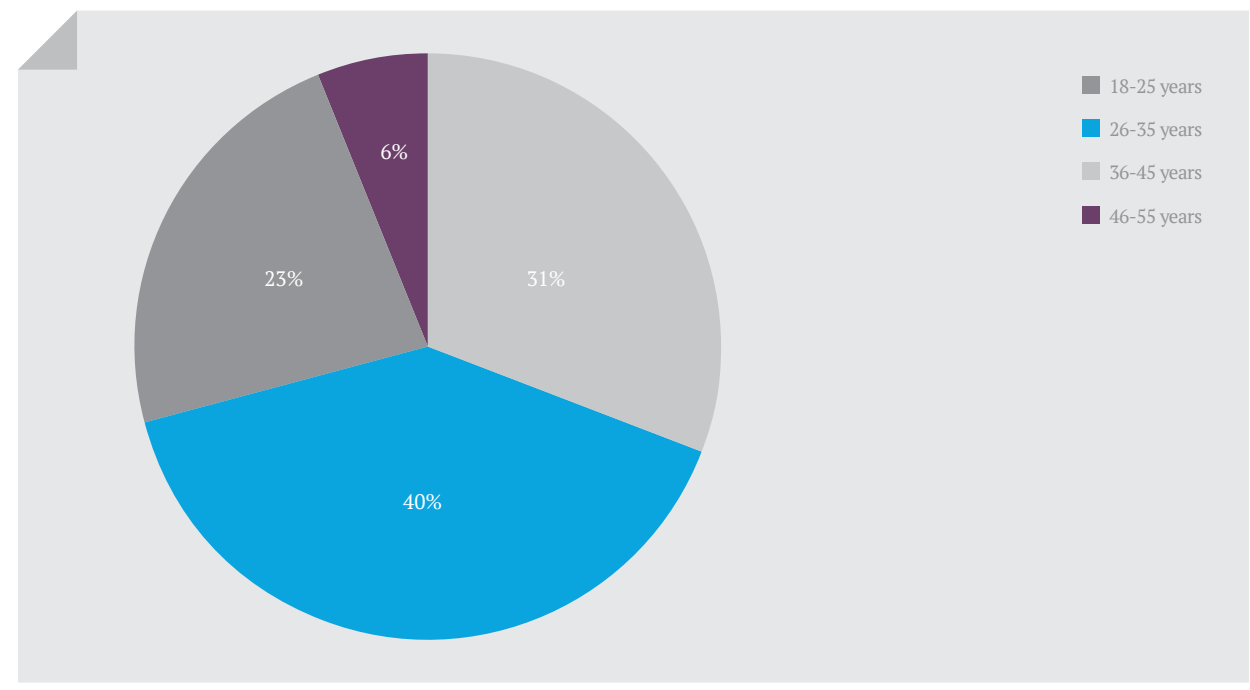

Figure 1. Respondents' age $(\mathrm{N}=35)$ 
The questionnaire was completed mostly by respondents from large companies with more than 250 employees (46\%), followed by respondents from small companies with up to 50 employees (40\%), whereas, the survey was least completed by public relations experts from medium-sized companies (14\%). The results show (Figure 2) that most of them (32\%) are working within corporate communications departments/public relations departments with 3-5 employees. Ten respondents (30\%) work alone or with one more person (29\%), while a department with more than 10 employees is not common (9\%). When it comes to PR departments and their position in organizations in Croatia, previous studies show that, in $56 \%$ of cases, there is a formal PR department within the organization, in $25 \%$ of cases only one person is responsible for PR, and in 19\%, there is no formal PR department. However, managers of PR departments are positioned close to the board of directors (37\%) or are a part of middle management (28\%), while in $5 \%$ of cases, PR managers are board members (HUOJ, GfK, 2009). Tasks overlapping between departments and PR agencies, pointed out by $9 \%$ of Croatian PR professionals (HUOJ, GfK, 2009), in a certain manner disable a precise view on how many people performing PR programmes over a certain period of time.

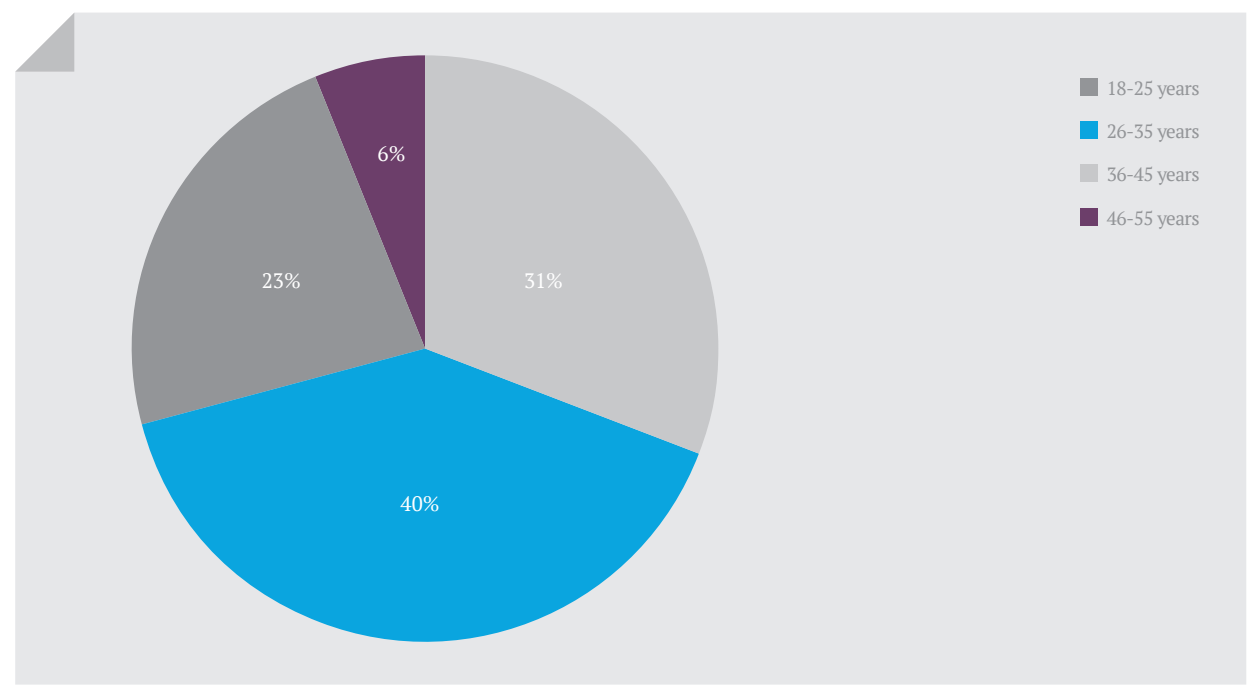

Figure 2. Number of employees in the PR department $(\mathrm{N}=35)$ 
While conducting the research, representation of different industries and areas of activity were taken into account. The survey was completed by most PR professionals from the trade sector (20\%), followed by $9 \%$ from the energy sector, telecommunications and the field of information technology. Next, $6 \%$ are employees in the manufacturing sector, transport, banking, tourism, marketing and services, and media and communications. PR experts from agriculture, pharmaceuticals, defence, automotive, business consulting and beverage sector (3\%) also participated in the survey research.

The question dealing with the position and status within the company revealed very interesting answers. The answers demonstrate a wide range of positions and roles that practitioners of public relations have. Most of the respondents answered that they hold PR manager positions (51\%), followed by junior consultant positions (14\%) and corporate communications associates (9\%). Furthermore, $6 \%$ hold PR director and junior consultant positions, while $3 \%$ are positioned as PR assistants, PR trainees/interns, heads of public relations, PR leads and PR executives.

To get an insight into the position and responsibility of the public relations/corporate communications department, we examined what role the PR department has in an organisation. Twenty-six percent of respondents identified that public relations department/ corporate communications department has an advisory role, while $18 \%$ see it as a part of the administrative service in an organisation, and the same percentage thinks that PR is involved in making business decisions. In both cases, $30 \%$ of respondents indicated that their department is not part of the administration, but also that it does not have an advisory role in the organization.

The research findings also showed which PR activities in the field of public relations within the corporate sector are the most frequent. The data (Figure 3) show that their activities usually consist of: sending posts and responses to the media (86\%), communication on the Internet, editing web pages and social networks (77\%) and internal communication (71\%). Less frequent activities are education, training and development (8\%) and relations with investors and management problems (8\%). Furthermore, respondents usually measure PR activity and communication on social networks (80\%) to assess the effectiveness of communication programmes. In $54 \%$ of cases, this approach is used for every PR program, while $14 \%$ do not use it at all. This is followed by press clipping (74\%) used for every 
PR campaign in $54 \%$ of cases while $11 \%$ never use it. One part of the respondents also measures activities on the official website (60\%). Only $20 \%$ of respondents measure the changes in attitudes and behaviours (20\%) and only $6 \%$ of them measure the impact on the financial results (6\%).

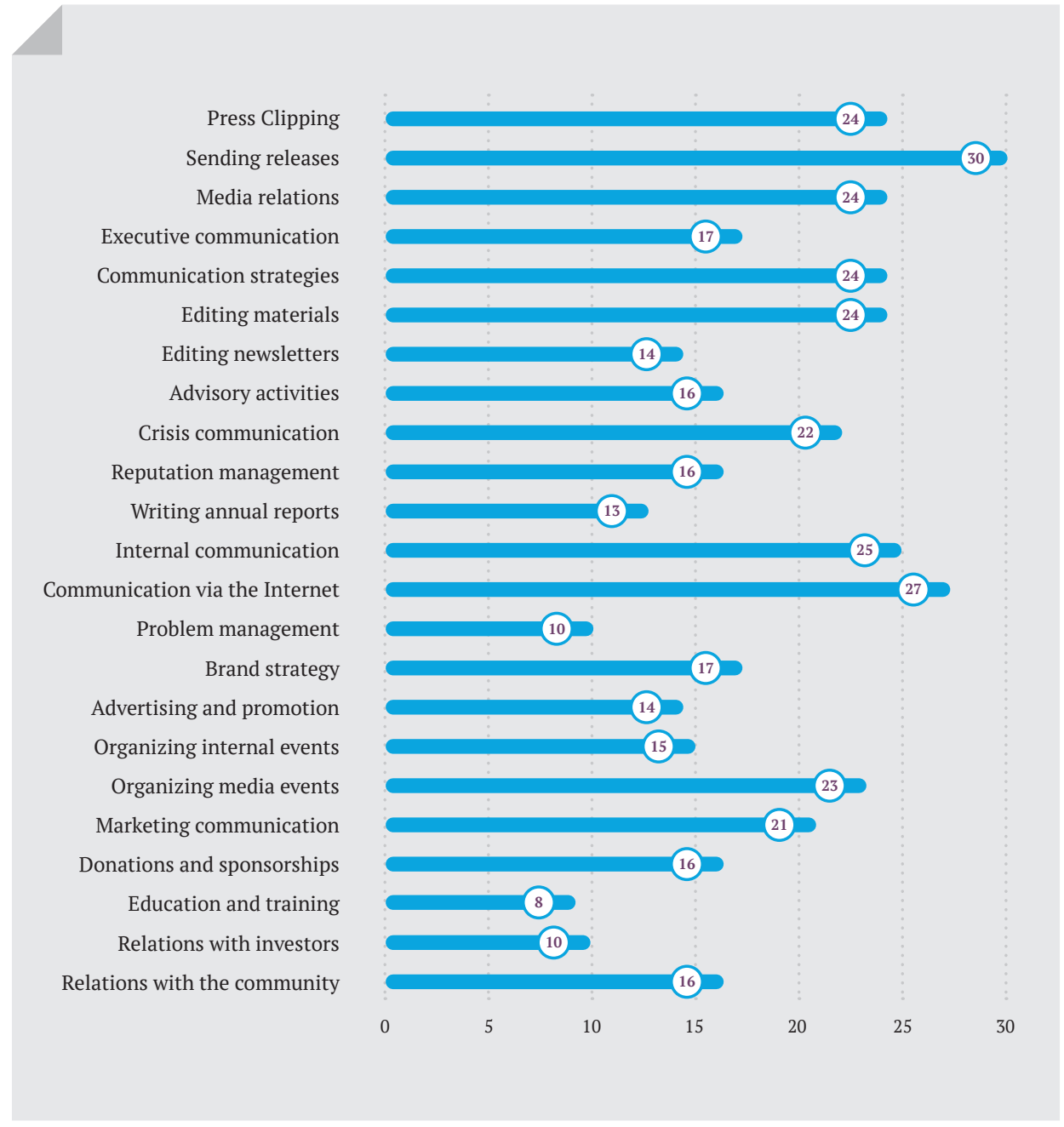

Figure 3. Activities within the PR department $(\mathrm{N}=30)$ 
We examined in what matter and with what tools respondents measure the success of their programmes on social media due to the increasing PR activities online and with regard to the importance of reaching targeted publics. Ultimately, we observed online evaluation with regard to the implementation of the online programmes and their effect on a company's profit. In the document, The Principles of PR Measurement (www.ketchum.com, 28.04.2016) it is clearly shown that social media have become an indispensable part of PR campaigns and a very important method of engagement and communication with the target audience. Social activity is not measured by $9 \%$ of respondents, while $17 \%$ answered that it is the task of colleagues from the digital marketing or external agencies engaged in digital marketing. As the most common methods of monitoring activity on social media, respondents point out measuring likes, sharing and reach. In addition, they measure the number of visits on the official Facebook page, the number of messages and response rate of community managers. The methods mentioned are also the number of followers on Instagram and user engagement rates. When it comes to tools, the majority of surveyed PR experts use Google analytics (19\%), but also Socialbakers, Spinklr, Iconosquare, Webtrekk and Facebook Insights.

When it comes to research methods for measuring the impact of PR programmes, respondents commonly use content analysis (57\%), followed by surveys (34\%) and focus groups (20\%). The least frequent method used is interviews (14\%), while $26 \%$ of respondents do not use research methods at all. Moreover, the effects of the programmes are usually measured on the cognitive level (51\%), then conative (43\%) and the least on the affective level (31\%).

The findings on implementation of PR evaluation in communication programmes are quite diverse. The results show (Figure 4) that, in $29 \%$ of cases, evaluation is carried out only for the most important programmes, in $17 \%$ of cases, it is conducted on an annual basis, and in $14 \%$, it is carried out for all communication programmes. In $11 \%$ of cases, evaluation is conducted by hired external PR agencies, while $23 \%$ percent of respondents answered that evaluation is not carried out at all. Finally, $6 \%$ of respondents are not sure whether evaluation in conducted for PR programmes in their departments.

Results on the importance of PR evaluation show that, for $89 \%$ of respondents, it is important or very important. On the other hand, the most common reasons for not conducting PR evaluation are (Figure 5): lack of staff (60\%), lack of time (54\%) and lack of sufficient financial resources (43\%). Interviewed PR experts also frequently mention lack of knowledge (29\%), 


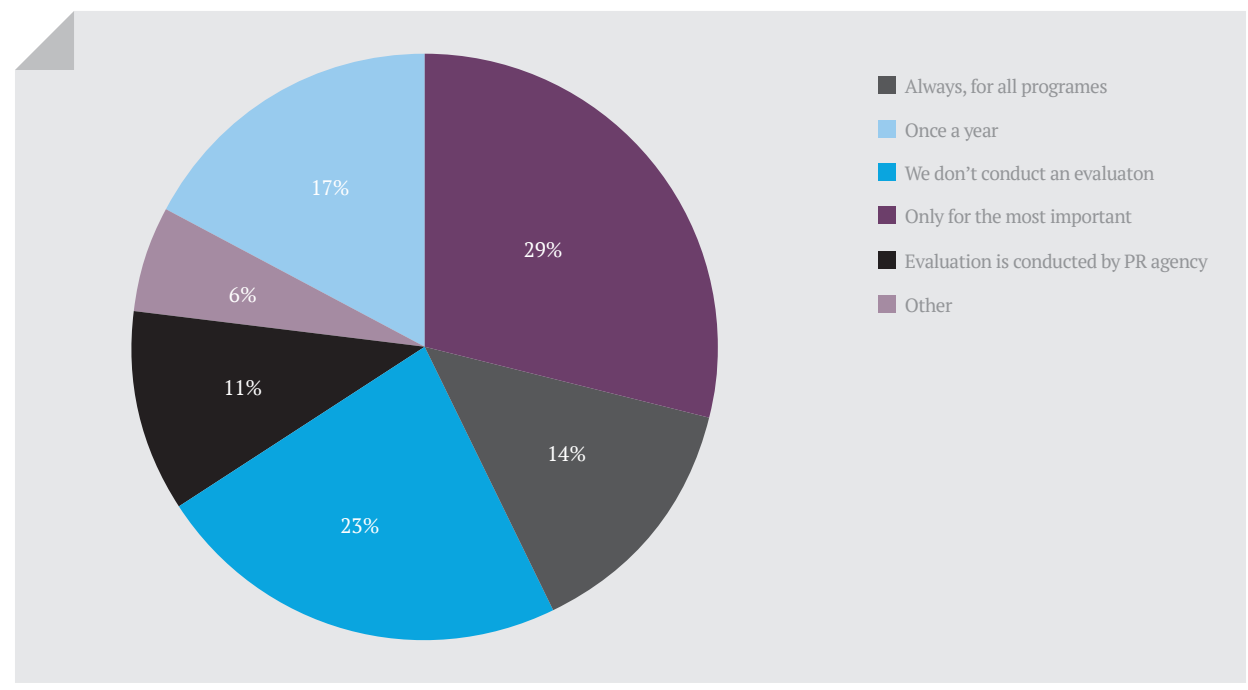

Figure 4. Frequency of PR evaluation $(\mathrm{N}=35)$

doubts in the benefits of the evaluation (17\%). To a lesser extent, respondents believe that evaluation results can expose PR practitioners to criticism (6\%) and they have an aversion to scientific methodology and constant changes in the company (3\%).

Research results for the frequency of evaluation on different levels of communications programs show that it is mostly used for planning upcoming communication activities. Forty percent of respondents do it always for planning upcoming communication activities, while $23 \%$ do it often. Respondents also use PR metrics to evaluate and measure the success of a communication strategy, $37 \%$ of respondents do this always and $29 \%$ often. Evaluation is least used for supervising a project team and controlling a PR agency (if an external PR agency was engaged in the project), $23 \%$ of respondents always use it for this and $11 \%$ often. Respondents use evaluation results to determine and verify the goals of communication programmes and to demonstrate the value of the communication programme to management (23\% of respondents always use it and $29 \%$ often). These results indicate a more frequent implementation of summative (measurement after completion of the PR programme with a focus on results and effects) versus formative evaluation (measurement during programme execution). 


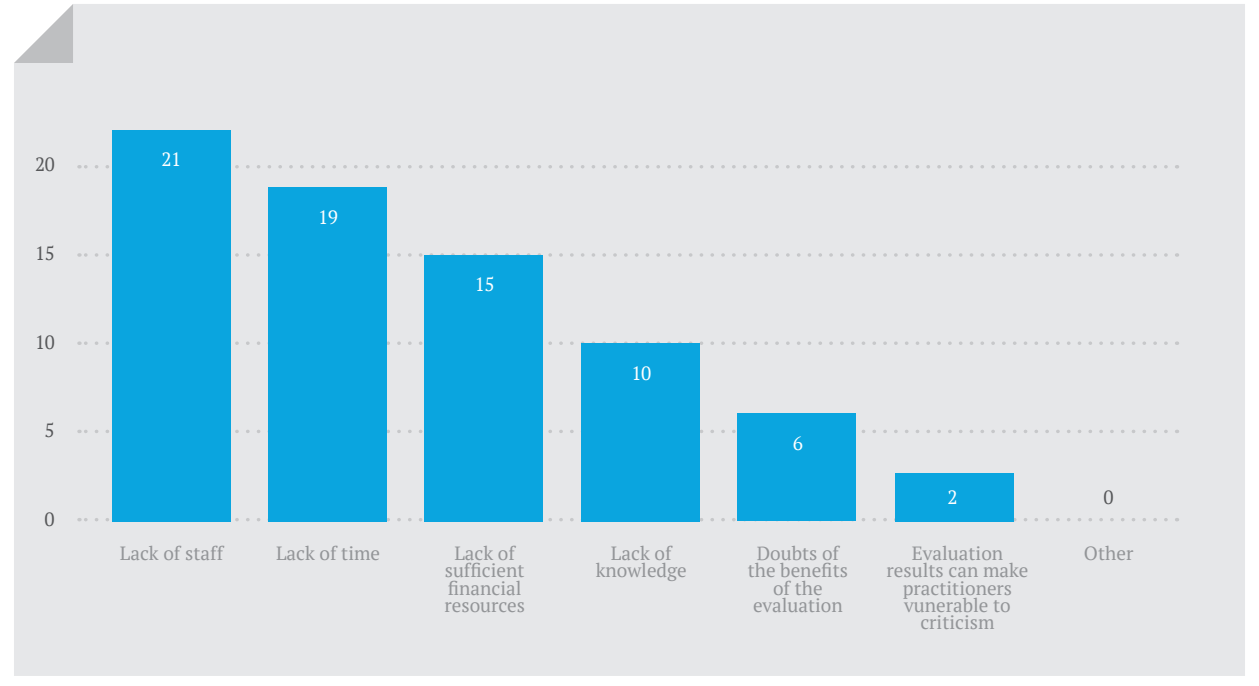

Figure 5. Reasons for not conducting PR evaluation $(\mathrm{N}=35)$

When respondents were asked to rate their own abilities to implement certain research methods and perform measurement, the highest number of respondents point out collecting and interpreting data ( $40 \%$ - very high capacity, $54 \%$ - high capacity), followed by the preparation and implementation of interviews (49 - very high, 26 - high competence), then designing and conducting surveys (31 - very high, 46 - high competence) and also content analysis (26\% - very high competence, $49 \%$ - high competence). Respondents are not so familiar with the method of focus groups (26\% - minimum competence, $29 \%$ - core competence). The most diverse findings show up with calculating the value of reputation/ brand (14\% - has no ability, $17 \%$ - minimum, while $20 \%$ of respondents indicates that there is a high or very high competence to implement this method) and for designing card communication performance (communication scorecards) - 20\% does not have the ability, on the other hand, $20 \%$ has a high or very high capacity. Furthermore, $4 \%$ of respondents indicated a very high and 31\% a high ability for using the analysis tools for the Internet and social media. The remaining methods are the following: budget analysis (34\% - very high capacity, $17 \%$ - high capacity) and an analysis of the process and flow of the programme (29\% core and a high capacity, $23 \%$ - very high competence). 
The results differ in certain matters in terms of organizational engagement with external agencies for public relations purposes. However, most of them (37\%) say that the budget for public relations/corporate communications includes costs of hiring external agencies, but that they do not have a need for their frequent engagement. A slightly lower percentage, $31 \%$, responded that they have space in the budget and that they engage agencies often. In $9 \%$ of cases, there is no space in the budget for the engagement of an external PR agency, while (17\%) of respondents answered that they have no need to engage external agencies. PR agencies usually conduct press clipping and analysis of media coverage (37\%), but also verification activities and communication on social media (20\%), when they are hired.

\section{Discussion}

The results of the survey research among Croatian PR professionals in the corporate sector show that evaluation and measurement of PR activities are not performed very often. This is supported with results, which indicate that $23 \%$ of respondents do not measure PR activities at all in their departments. Furthermore, $29 \%$ of respondents measure only the most important PR activities, while only $14 \%$ measure every PR activity. Nevertheless, respondents think that it is very important to measure PR activities (89\%). Other studies confirm this data by showing that PR professionals see evaluation as an important part of the PR profession but do not implement it in practice. Results on PR evaluation in Australia show that $90 \%$ of respondents see measurement as relevant but only $43 \%$ perform it in PR programmes (Walker, 1997, as cited in Watson, Noble, 2005).

The results show that the reasons for not conducting evaluation research exist. Two variables seem to be associated, for respondents the biggest obstacle is a small number of employees, PR practitioners in the organization (60\%), while the second most frequent answer is lack of time due to other tasks (54\%). The following most frequent answer is insufficient funds for conducting evaluation (43\%), which indicates that directors and the board are still not aware of the value of public relations nor its programmes and strategies.

PR professionals mostly use quantitative methods for evaluation and measurement, especially content analysis (57\%) and surveying (34\%), while $26 \%$ of respondents do not use research methods. Jugo (2012, p. 11) emphasizes that, in Croatia, trends show a low frequency of 
using research for planning in PR. In 2009 only 15\% of organizations conducted research for communication strategies while in 2003 it was one quarter more (Jugo, 2012).

When it comes to the most important PR activities in the corporate sector, the techniques that are most frequently used are news releases (86\%) and communication on social media (77\%). It is not surprising that PR professionals mostly use press clipping (74\%) for measurement and these results are in accordance with the European Communication Monitor (2015), as they show that PR practitioners prefer output measurement.

Social media represent the most recent issue and opportunity for public relations. The results show that Croatian PR professionals in the corporate sector are very aware and informed about online metrics. The majority of respondents (80\%) pointed out the importance of measurement on social media, where they especially value and track "like", "share" and "reach". For example, on Facebook respondents usually calculate "engagement rate". This approach enables the measurement of reach and interaction with regard to published PR messages. Results indicate that respondents use various analytical tools for social media - Google analytics (19\%), respondents also mentioned Socialbakers, Spinklr, Iconosquare, Webtrekk and Facebook Insights, while 17\% responded that, their colleagues from the digital marketing department measure efficiency. This shows that overlapping of two professions, public relations and marketing, is especially present online.

Results show that research is, in general, used for formative purposes, for situation analysis and planning, but also PR evaluation is performed more at the end of a PR programme than during the programme implementation. When it comes to methods used for PR evaluation, PR professionals show high competence for conducting interviews but they do not use this method very often.

The issue that especially arises from research findings are the various titles for public relations practitioners within the corporate sector. They are junior consultants, senior consultants, managers, directors. Apart from that, respondents also mention these titles: associate for corporate communications, PR leads and PR executives. Still, there is not a position strictly dedicated to PR evaluation, while it represents an important segment of the PR profession. 


\section{Conclusion}

The issue of PR evaluation and measurement is a significant and challenging topic for academics and practitioners. The main issue concerns the insufficient standardization of evaluation procedures with regard to fluidity of communication processes. Most authors agree that the first step towards successful measurement is determining measurable objectives of PR programmes. Evaluation is important because it can steer a campaign in the right direction. It helps in showing the results of PR activities as represented findings that prove PR value. If it is properly implemented it can save money and time necessary for PR activities.

Research among Croatian PR professionals in the corporate sector shows that evaluation is still not performed enough in PR practice. Furthermore, it is usually conducted as summative research. Croatian PR professionals more frequently use quantitative methods, survey and content analysis, than qualitative methods. Considering the responses of professionals in this survey research, a future study could focus and analyse, in a more qualitative manner, what PR practitioners actually imply when they mention the use of content analysis and other methods for evaluation. In other words, what is their level of knowledge for using research methods and implementing them for PR measurement.

Respondents agree that there is not enough time to perform evaluation and they do not have competent personnel to deal with this issue effectively. Improving this situation would imply education and training. Possible solution that should be taken into account is an increase in the budgets of PR departments and PR research. What can also be a bright moment for the future of PR in Croatia is that the majority of PR professionals agree that the evaluation of PR programmes is necessary.

\section{Reference List}

- Broom, B. M. (2010). Cutlip\&Center's: Učinkoviti odnosi s javnošću. Zagreb: MATE.

- CEPOR (2016). Izvješće o malim i srednjim poduzećima u Hrvatskoj - 2015. Zagreb: European Fund for Southeast Europe \& Hrvatske banke za obnovu i razvitak.

- Charlesworth, A. (2015). An Introduction to Social Media Marketing. New York: British Library Cataloguing in Publication Dana.

- Drucker, P. F. (1954). The practice of management. New York: Harper \& Row.

- Gregory, A. (2006). Odnosi s javnošću - planiranje i upravljanje kampanjama. Zagreb: Print.

- IPRA (1994). Public Relations Evaluation: Professional Accountability. IPRA Gold Paper, 11. 
- Jakopović, H. (2012). Odnosi s javnošću kao znastvena grana informacijskih i komunikacijskih znanosti. Medijske studije, 3 (5), 85-101.

- Jakopović, H. (2015). Povezanost imidža organizacije s medijskim objavama na internetu (Ph.D. Dissertation). Zagreb: Filozofski fakultet.

- Jugo, D. (2012). Strategije odnosa s javnošću. Zagreb: Profil.

- Kunczik, M. (2006). Odnosi s javnošću. Koncepti i teorije. Zagreb: Fakultet političkih znanosti.

- Lamza Posavec, V. (2006). Metode istraživanja u novinarstvu. Zagreb: Fakultet političkih znanosti.

- Lamza Posavec, V. (2015). Mjerenje javnosti - metodologijski i analitički pristupi istraživanju javnoga mnijenja. Zagreb: Institut društvenih znanosti Ivo Pilar.

- Lindenmann, W. K. (2006). Public Relations Research for Planning and Evaluation. Florida: Institute for Public Relations.

- Löwensberg, D. (2009). Corporate image, reputation and identity. In: Tench, R., Yeomans, R. (Eds.), Exploring Public Relations (pp. 237-251). Harlow: Pearson Education Limited.

- Macnamara, J. (2014). Emerging international standards for measurement and evaluation of public relations: A critical analysis. Public Relations Inquiry, 3 (1), 7-29.

- Macnamara, J. (2008). PR Metrics - Research for Planning \& Evaluation of PR \& Corporate Communication. Retrieved from: http://amecorg.com/wp-content/uploads/2011/10/PR-Metrics-Paper.pdf. December 06, 2016.

- Milas, G. (2009). Istraživačke metode u psihologiji i drugim društvenim znanostima. Zagreb: Naklada Slap.

- Milas, Z. (2011). Uvod u korporativnu komunikaciju. Teorijski pristupi i organizacijski modeli. Zagreb: Novelti Millenium.

- Nordstrom, K., Riderstrale J. (2009). Funky bussines zauvijek: Kako uživati kapitalizam. Zagreb: Difero.

- Skoko, B. (2006). Priručnik za razumijevanje odnosa s javnošću. Zagreb: MPR.

- Skoko, B. (2004). Odnosi s javnošću kao doprinos demokratizaciji i profesionalizaciji procesa javnoga komuniciranja. Politička misao, 41 (1), 92-101.

- Tench, R., Yeomans, L. (2009). Otkrivanje odnosa s javnošću. Zagreb: HUOJ.

- Theaker, A. (2007). Priručnik za odnose s javnošću. Zagreb: HUOJ.

- Tomić, Z. (2008). Odnosi s javnošću, Teorija i praksa. Sarajevo: Synopsis.

- Van Ruler, B., Tkalac Verčič, A., Verčič, D. (2010). Mjerenje i evaluacija u odnosima s javnošću. Zagreb: HUOJ.

- Vranjicanin, S. (2009). Politička ekonomija. Zagreb: Pravni fakultet Sveučilišta u Zagrebu.

- Watson, T., Noble, P. (2005). Evaluating Public Relations: A Best Practice. A Best Practice Guide to Public Relations Planning, Research and Evaluation. London, Philadelphia: Kogan Page.

\section{Internet Sources}

- CIPR State of the Profession 2016. Retrieved from: https://www.cipr.co.uk/sites/default/files/CIPR_StateofPR_16.pdf. December 05, 2016.

- European Communication Monitor (2015). Retrieved from: http://www.zerfass.de/ECM-WEBSITE/media/ECM2016-ResultsChartVersion.pdf. December 05, 2016.

- European Communication Monitor (2016). Retrieved from: http://www.zerfass.de/ECM-WEBSITE/media/ECM2016-ResultsChartVersion.pdf. December 05, 2016.

- HUOJ, GfK (2009). Istraživanje HUOJ-a o stanju u odnosima s javnošću u RH - 2009. Retrieved from: http://www.huoj.hr/ aktivnosti-udruge-istrazivanja/5-istrazivanje-huoj-a-o-stanju-u-odnosima-s-javnoscu-u-rh-2009-hr239. December 05, 2016.

- HUOJ, Ipsos puls (2013). Stanje struke odnosa s javnošću u Hrvatskoj. Retrieved from: http://www.huoj.hr/aktivnosti-udruge/ provedeno-huoj-evo-istrazivanje-o-stanju-struke-odnosa-s-javnoscu-u-hrvatskoj-2013-hr3759. December 05, 2016.

- HUOJ, Nastavlja se pozitivan trend ulaganja u oglašavanje u hrvatskim medijima. Retrieved from: http://www.huoj.hr/ index.php?opt=news\&id=4236\&lang=hr. December 05, 2016.

- Launch of Barcelona Principles 2.0 (2015). Retrieved from: http://amecorg.com/wp-content/uploads/2015/09/BarcelonaPrinciples-2.pdf. December 05, 2016.

- Ketchum Global Research \& Analytics (2013). The Principles of PR Measurement. Retrieved from: https://www.ketchum. com/sites/default/files/principles_of_pr_measurement_0.pdf. December 05, 2016. 


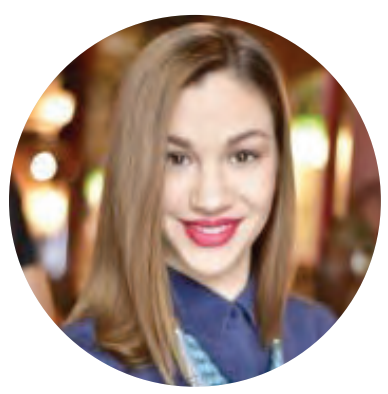

Ema Starčić

Ema Starčić has graduated Journalism and Public Relations at the Faculty of Political Science, University of Zagreb. She works as an anchor and journalist on Televizija Student. Previously she worked as PR manager at eStudent and as PR assistant at the HRT for the TV show The Voice.

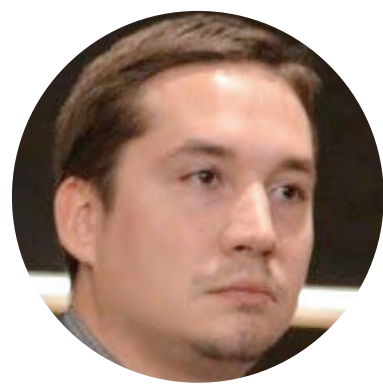

Hrvoje Jakopović

Hrvoje Jakopović is an Assistant Professor at the Faculty of Political Science, University of Zagreb where he teaches courses in public relations at the undergraduate and graduate level. He received his $\mathrm{PhD}$ degree in Information and Communication Sciences from University of Zagreb. He is Executive Editor Assistant of the scientific journal Media Studies and Deputy Director of the Postgraduate program in public relations at the Faculty of Political Science, University of Zagreb. He has published scientific articles in academic journals and book chapters on various topics in public relations. Some of his research interests include public relations evaluation, reputation measurement, sentiment analysis and media framing. 